\title{
Effect of Soil Solarization and Cover Crops on Populations of Selected Soilborne Plant Pathogens in Western Oregon
}

\author{
J. N. Pinkerton, USDA-ARS-HCRL, Corvallis, OR 97330; K. L. Ivors, M. L. Miller, and L. W. Moore, Depart- \\ ment of Botany and Plant Pathology, Oregon State University, Corvallis 97331
}

\begin{abstract}
Pinkerton, J. N., Ivors, K. L., Miller, M. L., and Moore, L. W. 2000. Effect of soil solarization and cover crops on populations of selected soilborne plant pathogens in western Oregon. Plant Dis. 84:952-960.

Field experiments were conducted in silty-clay loam in Corvallis, OR during the summers of 1995 and 1996 to study the effects of green manure cover crops (Sudan grass, rape, and barley), soil solarization, soil fumigation, and combinations of those treatments on population densities of soil pathogens Verticillium dahliae, Phytophthora cinnamomi, Pratylenchus penetrans, and Agrobacterium rhizogenes. Nylon mesh bags containing soil infested with $V$. dahliae and Phytophthora cinnamomi were buried $5,10,20$, and $30 \mathrm{~cm}$ deep. Soil solarization was performed over a 54- to 59-day period using a 0.6-mil clear polyethylene film. Maximum soil temperatures recorded at depths of $5,10,20$, and $30 \mathrm{~cm}$ were $53,48,39$, and $34^{\circ} \mathrm{C}$ in solarized soil, respectively; these temperatures were 8 to $16^{\circ} \mathrm{C}$ higher than in corresponding nonsolarized plots. Soil samples were collected before, during, and after solarization to quantify pathogen populations at those four depths. Pot or field studies were conducted subsequent to treatments to determine the effects of treatments on susceptible plants. Soil solarization, cover crops plus solarization, or fumigation with metam sodium resulted in a significant decrease $(P<0.05)$ in density of $P$. cinnamomi populations at all four depths and reduced $(P<0.05) V$. dahliae at 5 and $10 \mathrm{~cm}$. In greenhouse assays of solarized soils, disease severity was reduced $(P<0.05)$ for Verticillium spp. on eggplant and Phytophthora spp. on snapdragons. Cover crops alone were not effective in reducing P. cinnamomi and $V$. dahliae populations. Agrobacterium spp. population densities declined within solarized plots and incidence of crown gall on 'Mazzard' cherry rootstock planted in solarized plots was reduced significantly. Population densities of Pratylenchus penetrans were reduced in the upper $30-\mathrm{cm}$ soil profile by solarization. Solarization for an 8-week period during the warmest months of summer could provide an additional management alternative for several important soilborne pathogens in western Oregon.
\end{abstract}

Additional keywords: green manure, metam sodium, methyl bromide, root-lesion nematode, soil amendment

Due to the environmental hazards associated with soil fumigation by methyl bromide, a search for alternative methods of controlling soilborne pathogens has become a priority of the United States Department of Agriculture-Agricultural Research Service (USDA-ARS). A ban on the manufacture and importation of methyl bromide in the United States will be effective in 2005 due to concerns about its role in ozone depletion (9). This limitation leaves the agricultural industry in a transi-

Corresponding author: J. N. Pinkerton

E-mail: pinkertj@bcc.orst.edu

This research was funded in part by the Oregon Association of Nurserymen and the Oregon Department of Agriculture's Center for Applied Agricultural Research program.

Accepted for publication 15 May 2000.

Publication no. D-2000-0616-03R

This article is in the public domain and not copyrightable. It may be freely reprinted with customary crediting of the source. The American Phytopathological Society, 2000. tional situation, searching for other management tools. Therefore, the effects of alternative practices, such as cover cropping, soil solarization, applications of metam sodium, and combinations of these methods, need to be evaluated on populations of plant pathogens and disease incidence.

Soil solarization, the process of heating soils under transparent plastic tarps to temperatures detrimental to soilborne pathogens, has successfully controlled a variety of plant diseases (42). Solarization is a novel approach because it targets mesophyllic organisms, which include most plant pathogens and pests, without destroying the beneficial mycorrhizal fungi and growth-promoting Bacillus spp. $(39,41)$. Increased soil temperatures result in decreased populations of weeds (19) and a range of plant pathogens, including fungi (18), bacteria (35), and nematodes (43). If not directly inactivated by heat, soilborne plant pathogens may be weakened (13) and become vulnerable to soil fumigants, to other organisms, or to changes in the soil atmosphere in solarized soil $(39,40)$.
Greenberger et al. (14) demonstrated that solarized soils are often more suppressive to certain soilborne pathogens than nonsolarized soils. Pullman et al. (34) reported the effectiveness of solarization against Verticillium wilt in successive cultivations of safflower and cotton and Katan et al. (20) showed long-term effects of soil solarization against Fusarium oxysporum f. sp. vasinfectum in cotton for over 3 years. Several species of Phytophthora have been reported to be sensitive to high temperatures achieved through soil solarization $(17,30)$. Solarization for 6 weeks completely eradicated $P$. cinnamomi in South Africa (3) and controlled crown rot of cherry caused by $P$. cambivora for more than 12 months after treatment in Australia (49). Solarization reduced population densities of $F$. oxysporum $\mathrm{f}$. sp. vasinfectum and Verticillium dahliae by 94 to $100 \%$ at $5 \mathrm{~cm}$, by 67 to $100 \%$ at $15 \mathrm{~cm}$, and by 54 to $74 \%$ at $25 \mathrm{~cm}$ (22), eliminated V. dahliae to a depth of $120 \mathrm{~cm}$ in a pistachio grove without damaging the trees (1), and reduced the incidence of Verticillium wilt of potato in Idaho (11). Similarly, solar heating has shown promise for reducing Agrobacterium tumefaciens (35) and plantparasitic nematodes (43). Solarization has the added advantages of being safe and nonchemical and may enhance the effectiveness of other pest management approaches, such as biological control (42) and soil fumigation (4).

Cover cropping followed by incorporation of plant residues into soil has been reported to suppress certain soilborne pathogens and root diseases (10). The efficacy of various organic amendments for controlling soilborne plant pathogens has been attributed to the formation of toxic volatile compounds or to an increase in antagonistic soil microflora (37). For example, brassicas, which contain glucosinoates that break down to toxic isothiocynates (48), and Sudan grasses, which contain dhurrin that breaks down to hydrogen cyanide, have been reported to control phytonematodes $(15,27)$ and pathogenic fungi $(29,40)$. Not only can green manures provide an alternate disease control approach, they may increase nutrient availability, reduce ground water contamination, and stimulate beneficial microflora in the soil (2). Adding organic residues to the soil may increase the benefits of solarization (37).

In the Pacific Northwest, the nursery industry is a major agricultural sector with 
annual farmgate revenues in excess of $\$ 400$ million. Soilborne pathogens and pests cause substantial losses in many perennial, herbaceous, and woody nursery crops in the Pacific Northwest. In Oregon, hundreds of thousands of dollars of nursery crops are estimated to be lost due to $V$. dahliae and Phytophthora spp. on an annual basis. Crown gall, caused by pathogenic Agrobacterium spp., is also an economically important disease in Oregon nursery crops. Affected fruit trees and ornamental plants are not marketable and can cause severe economic losses to nurseries (35). Plant parasitic nematodes, such as Pratylenchus penetrans, have minor direct impact on plant growth in nursery production in the Pacific Northwest, but nematode-infested plants may not receive the phytosanitary certification required for interstate shipment. Solarization has been used successfully to control Verticillium wilt, crown gall, Phytophthora root rot, and plant-parasitic nematodes in subtropical and hot, arid regions, but its efficacy in controlling these pathogens in the temperate climate of the Pacific Northwest is unknown, with the exception of Agrobacterium spp. (35).

The objective of this study was to determine if solarization and cover cropping are feasible alternatives for simultaneously controlling a variety of important pathogens on nursery crops grown in the Pacific Northwest. These pathogens were Phytophthora cinnamoni Rands, $V$. dahliae Kleb., A. rhizogenes (Smith \& Townsend 1907) Conn 1942, and Pratylenchus penetrans (Cobb) Filipjev and SchuurmansStekhoven. Aspects evaluated in this study included determining whether climatic conditions in Oregon are adequate for soil solarization; and comparing soil solarization, cover cropping, soil fumigation, and combinations of these treatments for reducing populations of these pathogens or the severity of infection caused by them.

\section{MATERIALS AND METHODS}

Inocula production. An environmentally competent spontaneous mutant of pathogenic A. rhizogenes strain B49C/83 originally isolated from an apple tumor and resistant to rifampicin was selected for infesting field plots. The bacteria were grown on mannitol glutamate medium (28) with $1 \mathrm{~g}$ liter $^{-1}$ of yeast extract substituted for biotin (MGY) and amended with 100 $\mathrm{mg}$ liter $^{-1}$ of rifampicin. Bacteria were washed off the surface of the agar plates and suspended in water to give a final reading of 125 in a Klett Summerson colorimeter $\left(10^{9} \mathrm{CFU} \mathrm{ml} \mathrm{m}^{-1}\right)$.

The isolate of Phytophthora cinnamomi used in this study was originally obtained from western azalea (Rhododendron occidentale) in Oregon. Phytophthora spp. inoculum was prepared by growing the isolate in culture bags (L. F. Lambert Spawn Corp., Coatesville, PA) containing
$500 \mathrm{~cm}^{3}$ of sieved vermiculite (>2 mm), 40 $\mathrm{cm}^{3}$ of ground oats, and $250 \mathrm{ml}$ of $\mathrm{V} 8$ broth (V8 juice, $200 \mathrm{ml} ; \mathrm{CaCO}_{3}, 2 \mathrm{~g}$; and distilled water, $800 \mathrm{ml}$ ). The bags were autoclaved for $60 \mathrm{~min}$ on two consecutive days, allowed to cool, and inoculated with plugs taken from the margin of colonized corn meal agar (CMA) plates. After 3 weeks of incubation in the dark at $20^{\circ} \mathrm{C}$, the colonized blocks of inoculum were broken up in a food processor and evenly mixed in a 1:10 ratio with sterilized field soil in a cement mixer. Inoculum density in the 1:10 soil-inoculum mixture was assayed with a leaf disk method described below.

The culture of $V$. dahliae used in this study was originally isolated from Norway maple (Acer platanoides) obtained from a commercial nursery in Oregon. V. dahliae inoculum was prepared by growing singlespore isolates in culture bags containing $1,100 \mathrm{~cm}^{3}$ of soaked rye grain. The bags were autoclaved for $60 \mathrm{~min}$ on two consecutive days, allowed to cool, inoculated with $10 \mathrm{ml}$ of colonized Czapek-Dox broth, and incubated in the dark at $25^{\circ} \mathrm{C}$. After inoculating, the bags were shaken by hand every 3 or 4 days to keep the cultures from becoming solid masses. After full colonization of the rye (4 to 6 weeks), the grain was spread out on an open bench top to dry, then ground into a powder with a Wiley mill (A. H. Thomas Co., Philadelphia, PA) utilizing a 20-mesh screen. The inoculum density $\left(\mathrm{CFU} \mathrm{g}{ }^{-1}\right)$ of this powder was determined by the Andersen sampler technique (6) described below.

The effects of treatment on populations of Pratylenchus penetrans were only studied in 1995 in two fields at the Oregon State University (OSU) Botany and Plant Pathology Field Laboratory in Corvallis. One field had silty-clay loam and the other field had a loam soil. In April 1994, peppermint plants infested with $>1,000 P$. penetrans per gram of root were planted at a density of 9 plants $/ \mathrm{m}^{2}$ in each 2-by-2-m plot. After 12 months and before planting the cover crops, an aqueous solution of $1 \%$ glyphosate was applied to kill the stand of peppermint and weeds covering the plots.

Plot establishment. Field experiments were conducted during the summers of 1995 and 1996 in separate but adjacent plots on a silty-clay loam soil at the OSU Field Laboratory in Corvallis. Preceding solarization, each field had been left in weedy fallow for 4 years. On 22 May 1995 and 4 June 1996, V. dahliae, Phytophthora cinnamomi inocula, and urea (46-0-0 at 34 $\mathrm{kg} \mathrm{ha}^{-1}$ ) were broadcast on the surface of the soil and the plots were rotovated immediately to incorporate the inocula uniformly to a depth of $20 \mathrm{~cm}$. Seed of the cover crops were broadcast on the soil surface and incorporated with light raking. Seeding rates were Trudan 8 sorghum-Sudan grass hybrid (Sorghum bicolor $\times S$. vulagare), $111 \mathrm{~kg} \mathrm{ha}{ }^{-1}$; Mica barley

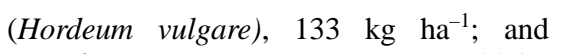
Dwarf Essex rape (Brassica napus), $33 \mathrm{~kg}$ $\mathrm{ha}^{-1}$. Cover crops were irrigated and weeded according to recommended practices for nursery production prior to incorporation in July. The experimental design in 1995 was a randomized split plot with four replications. An extra replicate and a methyl bromide treatment were added to the experimental design in 1996. The whole plots consisted of solarized and nonsolarized soils. Subplots consisted of (i) incorporated green manures, (ii) application of metam sodium, (iii) clean fallow, (iv) methyl bromide (nonsolarized plots in 1996 only), and (v) control plots not inoculated with any of the pathogens. Each treatment subplot was 2 by $2 \mathrm{~m}$ in size.

The depth to which solarization was effective was determined by burying nylon bags of artificially infested soil at various depths in each plot. This soil was prepared by mixing the following uniformly in a cement mixer: $V$. dahliae inoculum, $1.31 \times$ $10^{-3} \mathrm{~g} ;$ P. cinnamomi inoculum, $1.11 \times 10^{-1}$ $\mathrm{g}$; $60 \mathrm{ml}$ of distilled water, and $1 \mathrm{~kg}$ of sterilized silty-clay loam soil. A total of $250 \mathrm{~cm}^{3}$ of the mixture was loosely placed into fine nylon mesh bags (Leggís Products Inc., Henderson, NV) along with a plastic label to identify sample name and depth. The bags were knotted at the end and attached to monofilament lines with labels to assist in their recovery. These inoculum bags were buried in the soil within $48 \mathrm{~h}$ of preparation in respective plots.

Treatments. In mid-July of 1995 and late July of 1996, the cover crops were cut at ground level, chopped into pieces 10 to $15 \mathrm{~cm}$ long, and fresh weights were recorded. Before incorporating the green manure, each 2-by-2-m plot was sprayed with 2 liters of a $1 \times 10^{9} \mathrm{CFU} \mathrm{ml}^{-1}$ aqueous suspension of $A$. rhizogenes. Crop residue was spread over the plot from which it was harvested and the plots were rotovated to a depth of $20 \mathrm{~cm}$. Fallowed and metam sodium-treated plots also were rotovated. At this time, two sets of nylon bags containing fungal inocula were buried in each plot at depths of 5,10 , and $20 \mathrm{~cm}$ in 1995 and at depths of 5, 10, 20, and 30 $\mathrm{cm}$ in 1996. Plots were irrigated with an overhead sprinkler to bring the soil to field capacity. A 0.6-mil transparent polyethylene film (PolySource, San Diego, CA) was stretched tightly over the plots to be solarized and secured in place by burying the edges. The plots were solarized for 59 or 54 days from 21 July to 19 September and from 26 July to 18 September in 1995 and 1996, respectively. Nonsolarized plots were maintained weed free with applications of glyphosate and hand weeding during the solarization period. The metam sodium treatments were applied immediately after the July rotovation. Metam sodium was sprayed on the soil surface at 930 (nonsolarized) and 230 liters $\mathrm{ha}^{-1}$ (solarized and nonsolarized) in 2 liters of 
water per plot. The soil was rotovated immediately and then rolled to seal the surface. In 1996, subplots were tilled and prepared as before, and a methyl bromide with $2 \%$ cholorpicrin treatment was applied at $800 \mathrm{~kg} \mathrm{ha}^{-1}$.

Sampling. Soil samples were collected on four dates: immediately after infesting the plots, after incorporating the green manures, after 4 weeks of solarization, and when the solarization plastic was removed. Those dates were 22 May, 21 July, 18 August, and 19 September, respectively, in 1995 and 4 June, 26 July, 23 August, and 18 September, respectively, in 1996. Population densities of all introduced pathogens and selected beneficial microorganisms were determined in samples for each date. Eight soil cores $(2.5$ by $30 \mathrm{~cm})$ were collected from each plot, bulked, and thoroughly mixed for analysis. In addition, one inoculated soil bag in each plot from each depth was removed after 4 weeks and the second bag was collected when the plastic was removed.

Soil temperatures were recorded hourly in solarized and nonsolarized plots at depths of 5, 10, and $20 \mathrm{~cm}$ in 1995 and at $5,10,20$, and $30 \mathrm{~cm}$ in 1996 . A thermistor was placed at the given depths in the center of each plot and mean hourly temperatures were recorded with a CR21 micrologger (Campbell Scientific, Logan, Utah).

Assay procedures. A 100-g subsample of the bulked soil samples was processed for nematodes by the Baerman funnel method (46) for 5 days. All plant-parasitic nematode genera were counted in the samples collected at each date. A second set of subsamples was oven dried overnight at $121^{\circ} \mathrm{C}$ to determine the sample moisture content. Nematode population densities were standardized to a base line of $100 \mathrm{~g}$ of dry soil.

Agrobacterium spp. counts were made from soil samples taken in July and in September. Two soil samples of $10 \mathrm{~g}$ each were used, one sample to determine moisture content and the other for bacterial counts. Bacterial counts were made by suspending $10 \mathrm{~g}$ of soil in $90 \mathrm{ml}$ of sterile water in 250-ml flasks, then shaking these flasks on a rotary shaker for $1 \mathrm{~h}$. Serial dilutions were made from each suspension and three dilutions were spread plated in triplicate. Counts for Agrobacterium strain B49C/83 were made on selective medium $2 \mathrm{E}$ of Brisbane and Kerr (5) amended with $100 \mathrm{mg} \mathrm{liter}^{-1}$ rifampicin.

Natural populations of beneficial bacteria also were monitored in July before solarization and in September after solarization. These soil samples were processed in the same manner as the Agrobacterium spp. samples. Spore-forming bacteria (Bacillus spp.) were detected by heating soil suspensions to $80^{\circ} \mathrm{C}$ for $10 \mathrm{~min}$, then plating on nutrient agar amended with 0.2 g liter ${ }^{-1}$ cycloheximide. Fluorescent pseudomonads were counted on King B me- dium (28) amended with $0.2 \mathrm{~g} \mathrm{liter}^{-1} \mathrm{cy}$ cloheximide, and actinomycetes were enumerated by plating on MGY amended with $0.2 \mathrm{~g} \mathrm{liter}^{-1}$ cycloheximide.

The double-cup leaf disk method described by Linderman and Zeitoun (25) was used to recover and semiquantify $P$. cinnamomi from the bagged, artificially infested soil. A Styrofoam cup with its bottom replaced by a layer of cheesecloth was nested over $10 \mathrm{~g}$ of soil in a second intact cup. Twelve leaf disks $(9 \mathrm{~mm}$ in diameter) of eucalyptus (Eucalyptus gunnii) were floated in a hymexazol solution $\left(25 \mu \mathrm{g} \mathrm{ml}^{-1}\right)$ above the cheesecloth and soil for 3 days at room temperature under fluorescent lighting. The leaf disks were removed from the cups, blotted dry, and placed into PARP medium (pimaricin, vanocomycin, rifampicin, PCNB) amended with $50 \mu \mathrm{g} \mathrm{ml} \mathrm{m}^{-1}$ hymexazol (16). Plates were incubated in the dark for $72 \mathrm{~h}$ and examined for growth of $P$. cinnamomi. The estimate of inoculum quantity in a soil sample was expressed as percent colonized leaf disks.

The Andersen sampler technique (6) was used to estimate $V$. dahliae populations in field and bagged soil. Soil aggregates from each sample were broken up and thoroughly mixed. After air drying the soil at room temperature for 1 week, each sample was ground into a fine powder with a mortar and pestle. An Andersen air sampler was used to distribute the soil on the surface of NP-10 medium (38). Four replicate plates were processed for each sample. After 10 days of incubation in the dark at $20^{\circ} \mathrm{C}$, the surface of the agar medium was gently washed under a stream of water to remove soil particles, and microsclerotial colonies of $V$. dahliae were counted with the aid of a dissecting microscope. The estimate of soil inoculum density was expressed as an average number of CFU of $V$. dahliae $\mathrm{g}^{-1}$ of dry soil.

Soil bioassay. Snapdragons, hybrid Liberty Crimson (Antirrhinum majus, Goldsmith Seeds, Inc., Gilroy, CA), grown from seed in plug trays (Cyberplast Industries Ltd., Beaverton, MI), were used as indicator plants for the detection of $P$. cinnamomi in bagged soil. Ten-cell plastic plug trays were surface sterilized with $0.5 \% \mathrm{NaOCl}$ and cotton plugs were placed in the bottom of the cells. Trays were filled with a soil sample ( $5 \mathrm{~g}$ of soil per $50-\mathrm{ml}$ cell) and a single 4-week old snapdragon seedling plug was transplanted into each of the 10 cells and watered. Each 10-cell tray was placed on a wire mesh bench in the greenhouse, to eliminate the probability of cross contamination between samples, and arranged randomly. Control treatments consisted of snapdragons planted in autoclaved and oven-dried field soil. After 7 weeks, the plant heights were measured and plants were assessed for symptoms of infection (i.e., wilting, stunting, or death). Symptomatic and asymptomatic snapdragon roots from each treatment were assayed for $P$. cinnamomi. Roots were disinfested by thoroughly washing the root system in tap water for $10 \mathrm{~min}$, blotting dry, cutting the roots into $1-\mathrm{cm}$ sections with a sterile scalpel, and plating on PARP amended with 50 $\mu \mathrm{g} \mathrm{ml}^{-1}$ hymexazol. Plates were incubated in the dark at $20^{\circ} \mathrm{C}$ for 1 week and checked for $P$. cinnamomi.

Eggplants, cv. Imperial Black Beauty (Solanum melongena L.), grown from seed were used as indicator plants for the detection of $V$. dahliae in 1996. Soil samples were removed from cold storage and mixed thoroughly. A 25-g subsample of each was placed on top of sterilized potting mix in a 160-ml "super cell" tube (Ray Leach Container, Stuewe and Sons, Corvallis, OR) into which a 4-week-old eggplant was transplanted. Because of space limitations, treatment comparisons were restricted to samples buried below $5 \mathrm{~cm}$ where plating assay indicated greater survival of microsclerotia. Control plants were planted in sterilized field soil. In the greenhouse, all eggplants were fertilized once a week with a water-soluble fertilizer (20-20-20 Peters; Scott-Sierra Co., Marysville, OH). After 8 weeks, the plants were harvested and the roots and shoots of each eggplant were dried and weighed to measure total plant biomass and to assess treatment differences. Symptomatic and asymptotic roots from each treatment were assayed for $V$. dahliae. Roots were surface disinfested with $0.05 \% \mathrm{NaOCl}$ for $15 \mathrm{sec}$, rinsed with sterile water, cut into $1-\mathrm{cm}$ pieces, and plated on NP-10 media. Plates were incubated in the dark at $24^{\circ} \mathrm{C}$ for 2 weeks and checked for characteristic $V$. dahliae growth.

Eight months following solarization, 25 euonymus plants (Euonymus japonica) 50 to 100 'Mazzard' cherry trees (Prunus avium), and 25 maple trees (Acer rubrum in 1996 and A. plantoides in 1997) were planted in all plots to determine the level of field plant infection due to P. cinnamoni, $A$. rhizogenes, and $V$. dahliae, respectively. All plants were root pruned prior to planting to promote infection by A. rhizogenes. After 12 months, the cherry trees were dug and the number of galls on the roots were counted. At this time, the height of the maple trees was measured and the trees were rated for symptoms of Verticillium wilt. Verticillium ratings were assigned to five categories, where $1=$ no symptoms, 2 = few to $9 \%$ of leaves symptomatic, $3=10$ to $49 \%$ of leaves symptomatic, $4=>50 \%$ of leaves symptomatic of Verticillium wilt, and $5=$ dead tree. Because of poor initial survival of euonymus plants, the field assay for Phytophthora root rot was discontinued.

Data analysis. Significance of treatment differences was determined with SAS (SAS Institute, Inc., Cary, NC) by analysis of variance (ANOVA) using the general linear model procedure. Means were sepa- 
rated by least significant difference using Waller-Duncan tests.

\section{RESULTS}

Soil temperatures. The maximum soil temperatures recorded during both years in the upper $20 \mathrm{~cm}$ of soil were 10 to $16^{\circ} \mathrm{C}$ higher in solarized plots than in the nonsolarized plots (Table 1). Maximum soil temperatures reached in solarized plots were $53,48,39$, and $34^{\circ} \mathrm{C}$ at $5,10,20$, and $30 \mathrm{~cm}$, respectively. The seasonal pattern of daily maximum soil temperatures was similar in both years, so only the 1996 data are presented (Fig. 1). As an estimation of the thermal dose achieved in each season, the cumulative hours of temperatures greater than 35,40 , and $45^{\circ} \mathrm{C}$ were calculated (Table 1).

Verticillium spp. evaluation. All treatments, except nonsolarized Sudan grass in 1995, significantly reduced $V$. dahliae population densities in bulk field soil compared to the nonsolarized control after 2 months of solarization (Table 2). Green manure crops were not as effective as solarization in reducing Verticillium spp. densities, nor did they enhance the efficacy of solarization. In 1995, solarization reduced $V$. dahliae populations as effectively as metam sodium at 930 liters $\mathrm{ha}^{-1}$, but metam sodium and methyl bromide were more effective than solarization in 1996. Survival of $V$. dahliae propagules from buried bags of soil decreased in all treatments at all depths compared to the control, but this effect diminished with increasing depth (Table 3). In the upper 5 and $10 \mathrm{~cm}$, solarization treatments were as effective as soil fumigation and significantly better than green manure treatments. At 20 and $30 \mathrm{~cm}$, the survival of $V$. dahliae indicated that solarization was no more effective than green manure treatments. Fumigation with methyl bromide or metam sodium at 930 liters ha $^{-1}$ gave significantly greater control of $V$. dahliae at 20 and 30 $\mathrm{cm}$ compared to all other treatments. At all depths, the 230 liters $\mathrm{ha}^{-1}$ rate of metam sodium, with or without solarization, was never more effective than other solarization treatments.

Red maple trees planted in the plots treated in 1995 remained asymptomatic of
Verticillium wilt through 1998. Norway maple trees planted in plots treated in 1996 developed symptoms of Verticillium wilt in 1998 and were visually rated in July 1998. The ranking of treatments by disease ratings (Table 4) and tree height corresponded with the Verticillium spp. population densities determined by plating bulk field soil. Trees planted in soil fumigated with methyl bromide were symptomless and taller than trees in the other treatments. Trees grown in solarized plots generally had a lower disease rating and were taller than the trees in the paired, nonsolarized treatment, but those differences were not significant $(P>0.05)$.

Weights of eggplants planted in soil that had been buried at 10 and $20 \mathrm{~cm}$ were greater $(P<0.01)$ for solarized than nonsolarized soil (Table 5). At $30 \mathrm{~cm}$, the effects of solarization were only evident in soil from the barley plots. Biomass of eggplants was greater in fumigated soils than in solarized soils. $V$. dahliae was isolated only from the roots of symptomatic eggplants grown in inoculated soil and not from roots of plants grown in fumigated soil.
Phytophthora spp. evaluation. We were unable to quantify $P$. cinnamomi from bulk soil because a hymexazol-resistant Pythium sp. present in this soil grew rapidly over the PARP medium in bait leaf assays. However, Phytophthora cinnamomi was semiquantified in baited leaf assays of artificially infested soil that was buried in bags. In assays of soil before burying the bags, $100 \%$ of the leaf disks were infected. In both years, solarization reduced $P$. cinnamomi to below detectable levels in the upper $10 \mathrm{~cm}$ and was as effective as soil fumigation with metam sodium and methyl bromide (Table 6). At 20 and $30 \mathrm{~cm}$, a lower percentage of disks $(P<0.01)$ were infected in assays of solarized and fumigated soil than in soil collected from nonsolarized plots. Solarization was as effective as fumigation at $20 \mathrm{~cm}$ in 1995 and 1996. Green manures reduced $(P<0.01)$ recovery of $P$. cinnamomi at 5 and $10 \mathrm{~cm}$ compared to the control, but they did not enhance the efficacy of solarization.

Results of the snapdragon bioassay were not significantly different between years; hence, only the 1996 data are presented (Table 6). The mean height of assay plants

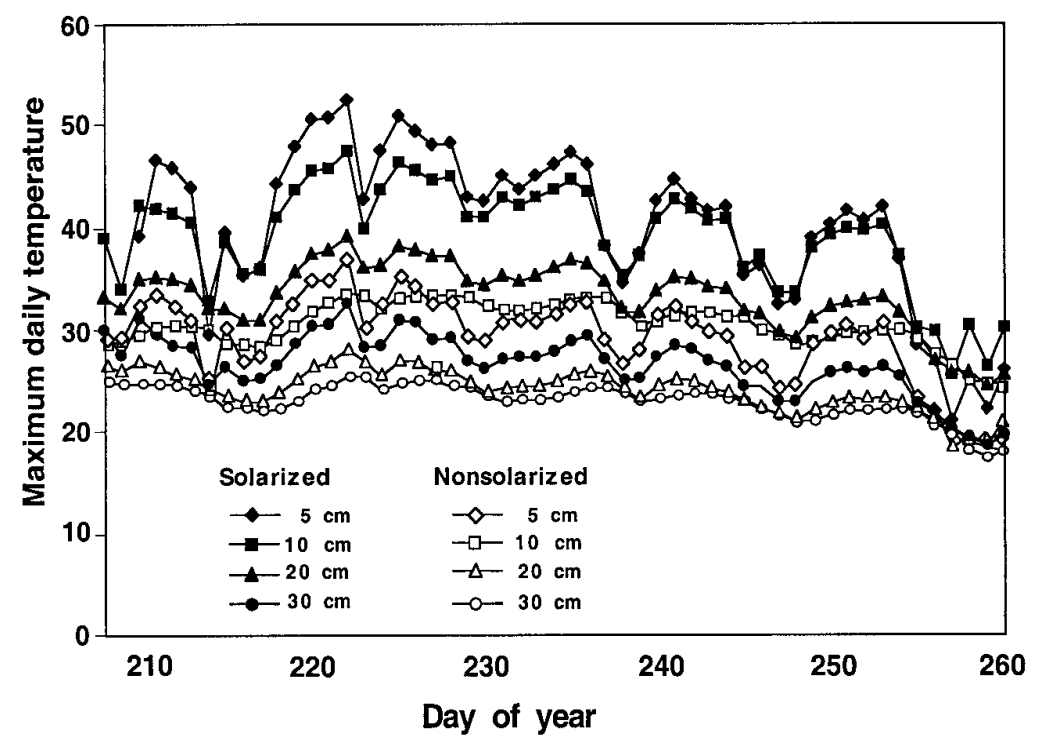

Fig. 1. Maximum daily soil temperature at four depths in solarized and nonsolarized plots at Corvallis, OR from 26 July to 18 September 1996.

Table 1. Soil temperatures in solarized and nonsolarized plots in 1995 and $1996^{z}$

\begin{tabular}{|c|c|c|c|c|c|c|c|c|}
\hline \multirow[b]{3}{*}{ Solarization period } & \multirow[b]{3}{*}{ Depth (cm) } & \multicolumn{4}{|c|}{ Soil temperature $\left({ }^{\circ} \mathrm{C}\right)$} & & & \\
\hline & & \multicolumn{2}{|c|}{ Solarized plots } & \multicolumn{2}{|c|}{ Nonsolarized plots } & \multicolumn{3}{|c|}{ Cumulative hours in solarized plots } \\
\hline & & Mean & Maximum & Mean & Maximum & $>35^{\circ} \mathrm{C}$ & $>40^{\circ} \mathrm{C}$ & $>45^{\circ} \mathrm{C}$ \\
\hline \multirow[t]{3}{*}{21 July-19 Sept. 1995} & 5 & 31.7 & 49.3 & 23.2 & 34.5 & 399 & 195 & 53 \\
\hline & 10 & 33.1 & 45.9 & 23.4 & 31.2 & 445 & 160 & 9 \\
\hline & 20 & 31.0 & 37.4 & 22.8 & 27.4 & 75 & 0 & 0 \\
\hline \multirow[t]{4}{*}{26 July-18 Sept. 1996} & 5 & 29.3 & 52.6 & 22.9 & 37.0 & 309 & 169 & 66 \\
\hline & 10 & 31.7 & 47.6 & 23.6 & 32.7 & 390 & 152 & 17 \\
\hline & 20 & 29.9 & 39.1 & 22.4 & 28.0 & 101 & 0 & 0 \\
\hline & 30 & 29.2 & 33.6 & 22.2 & 25.4 & 0 & 0 & 0 \\
\hline
\end{tabular}

\footnotetext{
$\mathrm{z}$ Thermocouples were buried at each depth in one solarized and one nonsolarized plot. Temperatures were recorded hourly by a datalogger. Plots were
} located in adjacent fields of silty clay soil on the Oregon State University Plant Pathology Field Station at Corvallis. 
grown in soil from the various treatments were in close agreement with the percent infection in the leaf-baiting assay. Snapdragons grown in infested soil that had been buried at 10 and $20 \mathrm{~cm}$ in solarized plots were taller $(P<0.01)$ than plants grown in soil from the paired, nonsolarized plots. There were no differences in heights $(P<0.01)$ between plants grown in solarized, fallow soil and in soil from fumigated plots. P. cinnamomi was isolated only from symptomatic seedling roots; no symptoms were observed in plants grown in noninoculated control soil or sterilized field soil.

Agrobacterium spp. evaluation. Population densities of rifampicin-resistant Agrobacterium spp. in bulk field soil declined significantly in 1995, but not in 1996, in all solarized and fumigated plots (Table 2). ANOVA of paired, homologous solarized and nonsolarized plots showed that Agrobacterium spp. counts were sig- nificantly lower $(P<0.01)$ in solarized compared to nonsolarized plots in all cover crop and fallow treatments. The incidence of galls on cherry trees planted in the 1995 plots was negligible, but in the 1996 plots, the percentage of cherry trees with galled roots was significantly lower in solarized plots compared to nonsolarized plots (Table 4). Methyl bromide did not reduce the incidence of trees with galls below that of the solarization control.

Table 2. Effects of soil solarization, green manures, and fumigation on the population densities of introduced soilborne plant pathogens in the upper 30-cm soil profile

\begin{tabular}{|c|c|c|c|c|c|c|}
\hline \multirow[b]{2}{*}{ Treatment } & \multicolumn{2}{|c|}{ V. dahliae ${ }^{\mathrm{v}}$} & \multicolumn{2}{|c|}{ Agrobacterium spp. ${ }^{w}$} & \multicolumn{2}{|c|}{ P. penetrans ${ }^{\mathrm{x}}$} \\
\hline & 1995 & 1996 & 1995 & 1996 & 1995 & 1995 loam \\
\hline Control, noninfested & $0.0 \mathrm{~d}$ & $2.5 \mathrm{e}$ & $1.05 \mathrm{a}$ & $2.83 \mathrm{bcd}$ & NT & NTy \\
\hline Control, solarized & $4.7 \mathrm{~cd}$ & $51.9 \mathrm{c}$ & $2.19 \mathrm{~b}$ & $2.41 \mathrm{bc}$ & 4 & $6 a$ \\
\hline Control, nonsolarized & $39.8 \mathrm{a}$ & $140.0 \mathrm{a}$ & $4.25 \mathrm{de}$ & 3.77 cde & 10 & $29 \mathrm{~b}$ \\
\hline Barley, solarized & $3.1 \mathrm{~cd}$ & $25.6 \mathrm{~d}$ & 3.04 cde & 3.09 bcde & 14 & NT \\
\hline Barley, nonsolarized & $6.3 \mathrm{c}$ & $54.4 \mathrm{c}$ & 4.30 ef & 3.79 cde & 19 & NT \\
\hline Rape, solarized & $5.1 \mathrm{~cd}$ & $47.5 \mathrm{c}$ & $2.68 \mathrm{bc}$ & $2.57 \mathrm{bcd}$ & 3 & NT \\
\hline Rape, nonsolarized & $21.9 \mathrm{~b}$ & $90.0 \mathrm{~b}$ & $4.56 \mathrm{fg}$ & $3.95 \mathrm{de}$ & 29 & NT \\
\hline Sudan, solarized & $3.9 \mathrm{~cd}$ & $45.0 \mathrm{c}$ & $2.37 \mathrm{bc}$ & $2.51 \mathrm{bcd}$ & 3 & NT \\
\hline Sudan, nonsolarized & $38.3 \mathrm{a}$ & $86.9 \mathrm{~b}$ & $5.13 \mathrm{~g}$ & $4.40 \mathrm{e}$ & 20 & NT \\
\hline Metam 230, solarized & $4.3 \mathrm{~cd}$ & $50.0 \mathrm{c}$ & $2.44 \mathrm{~b}$ & $1.96 \mathrm{ab}$ & 1 & NT \\
\hline Metam 230, nonsolarized & $16.8 \mathrm{~b}$ & $84.4 \mathrm{~b}$ & $3.70 \mathrm{de}$ & 3.24 bcde & 2 & NT \\
\hline Metam 930, nonsolarized & $2.7 \mathrm{~cd}$ & $8.8 \mathrm{e}$ & 3.00 ef & $0.91 \mathrm{a}$ & 3 & NT \\
\hline Methyl bromide, nonsolarized & NT & $0.6 \mathrm{e}$ & NT & $1.86 \mathrm{ab}$ & NT & NT \\
\hline Initial inoculum density & $91^{\mathrm{z}}$ & 203 & 5.52 & 5.53 & 37 & 42 \\
\hline
\end{tabular}

" Plots were located on adjacent fields of silty clay soil or on a field of loam soil on the Oregon State University Plant Pathology Field Station at Corvallis. Verticillium dahliae and Agrobacterium spp. were broadcast on the soil and incorporated to approximately $20 \mathrm{~cm}$. Pratylenchus penetrans was introduced on infested peppermint plants planted in 1994. Solarized plots were covered with a 0.6-mil clear polyethylene film for 2 months from midJuly to mid-September. Cover crops were planted in May each year and incorporated as green manures in mid-July. Metam sodium was applied on the soil surface at 230 or 930 liters ha ${ }^{-1}$ and mechanically incorporated. Methyl bromide was applied at $820 \mathrm{~kg} \mathrm{ha}^{-1} \mathrm{under}$ a plastic film. Means within columns followed by different letters were significantly different $(P<0.01)$ according to the Waller-Duncan procedure. No letters indicate no significant differences.

v Post-solarization population densities (CFU g-1 dry soil), 22 May 1995 and 4 June 1996.

${ }^{w}$ Post-solarization population densities ( $\log _{10}$ CFU g ${ }^{-1}$ dry soil), 19 September 1995 and 18 September 1996.

x The 1995 study compared cover crop, solarization, and fumigation treatments on a silty clay soil; 1995 loam study compared only solarized and nonsolarized treatments on a loam soil. Post-solarization population densities (nematodes $100 \mathrm{~g}^{-1}$ dry soil in upper 30 -cm soil profile), 19 September 1995.

${ }^{\text {y }}$ No treatment was made.

${ }^{\mathrm{z}}$ Initial mean population densities in June.

Table 3. Population densities of Verticillium dahliae in artificially infested soil after two months burial at three depths in solarized, fumigated, or covercropped field plots at Corvallis, OR ${ }^{\mathrm{w}}$

\begin{tabular}{|c|c|c|c|c|c|c|c|}
\hline \multirow[b]{3}{*}{ Treatment $^{y}$} & \multicolumn{7}{|c|}{ V. dahliae counts $\left(\mathrm{CFU} \mathrm{\textrm {g } ^ { - 1 }} \text { dry soil }\right)^{\mathrm{x}}$} \\
\hline & \multicolumn{3}{|c|}{1995} & \multicolumn{4}{|c|}{1996} \\
\hline & $5 \mathrm{~cm}$ & $10 \mathrm{~cm}$ & $20 \mathrm{~cm}$ & $5 \mathrm{~cm}$ & $10 \mathrm{~cm}$ & $20 \mathrm{~cm}$ & $30 \mathrm{~cm}$ \\
\hline Control, solar & $4.5 \mathrm{~d}$ & 22.5 de & $57.0 \mathrm{~b}$ & $1.2 \mathrm{c}$ & $12.8 \mathrm{de}$ & $42.0 \mathrm{de}$ & $75.2 \mathrm{bcd}$ \\
\hline Control, nonsolar & $101.5 \mathrm{a}$ & $115.3 \mathrm{a}$ & $170.8 \mathrm{a}$ & $162.6 \mathrm{a}$ & $189.2 \mathrm{a}$ & $203.2 \mathrm{a}$ & $204.4 \mathrm{a}$ \\
\hline Barley, solar & $2.8 \mathrm{~d}$ & $5.0 \mathrm{fg}$ & $22.5 \mathrm{ef}$ & $0 \mathrm{c}$ & $6.4 \mathrm{efg}$ & $25.2 \mathrm{e}$ & $47.6 \mathrm{e}$ \\
\hline Barley, nonsolar & $50.3 \mathrm{c}$ & $35.8 \mathrm{c}$ & $27.0 \mathrm{e}$ & $12.6 \mathrm{~b}$ & $23.0 \mathrm{~cd}$ & $38.8 \mathrm{de}$ & $48.2 \mathrm{e}$ \\
\hline Rape, solar & $0 \mathrm{~d}$ & $2.5 \mathrm{~g}$ & $30.8 \mathrm{de}$ & $0 \mathrm{c}$ & $1.8 \mathrm{efg}$ & $43.8 \mathrm{de}$ & $57.4 \mathrm{de}$ \\
\hline Rape, nonsolar & $75.5 \mathrm{~b}$ & $49.5 \mathrm{~b}$ & $40.3 \mathrm{~cd}$ & $19.6 \mathrm{~b}$ & $41.4 \mathrm{~b}$ & $65.6 \mathrm{bc}$ & $91.4 \mathrm{~b}$ \\
\hline Sudan, solar & $0.5 \mathrm{~d}$ & $4.8 \mathrm{fg}$ & $12.5 \mathrm{fg}$ & $1.2 \mathrm{c}$ & $11.2 \mathrm{ef}$ & $46.8 \mathrm{~cd}$ & 62.6 cde \\
\hline Sudan, nonsolar & $58.0 \mathrm{c}$ & $31.3 \mathrm{~cd}$ & $42.0 \mathrm{c}$ & $19.4 \mathrm{~b}$ & $33.6 \mathrm{bc}$ & $78.8 \mathrm{~b}$ & $87.0 \mathrm{bc}$ \\
\hline Metam 230, solar & $2.8 \mathrm{~d}$ & $14.8 \mathrm{ef}$ & $46.8 \mathrm{bc}$ & $0.6 \mathrm{c}$ & $3.0 \mathrm{efg}$ & $30.0 \mathrm{de}$ & 71.4 bcde \\
\hline Metam 230, nonsolar & $0.5 \mathrm{~d}$ & $9.0 \mathrm{fg}$ & $47.3 \mathrm{bc}$ & $1.8 \mathrm{c}$ & $10.4 \mathrm{efg}$ & $39.4 \mathrm{de}$ & 69.0 bcde \\
\hline Metam 930, nonsolar & $1.8 \mathrm{~d}$ & $2.3 \mathrm{~g}$ & $7.3 \mathrm{fg}$ & $0 \mathrm{c}$ & $1.2 \mathrm{fg}$ & $3.8 \mathrm{f}$ & $5.0 \mathrm{f}$ \\
\hline Methyl bromide, nonsolar & $\mathrm{NT}^{\mathrm{z}}$ & NT & NT & $0 \mathrm{c}$ & $0 \mathrm{~g}$ & $0.6 \mathrm{f}$ & $1.2 \mathrm{f}$ \\
\hline
\end{tabular}

${ }^{\mathrm{w}} V$. dahliae inoculum was grown on rye grain, ground, and mixed into pasteurized silty clay loam soil collected from the field plots to yield 302 and 234 CFU g ${ }^{-1}$ soil in 1995 and 1996, respectively. Infested soil was placed in nylon mess bags and buried in plots in at the start of the solarization period.

x Soil was dispersed on Sorensen's NP-10 medium with a Andersen sampler. Verticillium spp. colonies were counted after 10 days. Mean values within columns followed by different letters were significantly different $(P<0.01)$ according to the Waller-Duncan procedure.

y Solarized plots were covered with a 0.6-mil clear polyethylene film for 2 months from mid-July to mid-September. Cover crops were planted in May each year and incorporated as green manures in late July. Metam sodium was applied on the soil surface at 230 or 930 liters ha ${ }^{-1}$ and mechanically incorporated. Methyl bromide was applied at $820 \mathrm{~kg} \mathrm{ha}^{-1}$ under the plastic film.

${ }^{\mathrm{z}}$ No treatment was made. 
Pratylenchus spp. evaluation. Solarization reduced the population densities of $P$. penetrans compared to the paired nonsolarized treatments in 1995 (Table 2). Because of the great variability in nematode population densities at the start of the study, these differences were statistically significant only in the loam soil. Fumigation with metam sodium was no more effective in reducing $P$. penetrans population densities in the silty-clay loam soil than solarization alone. None of the treatments depressed nematode densities below the detection threshold.

Beneficial soil microflora. Sporeforming bacteria and fluorescent Pseudomonas spp. populations were stable in soil plots where cover crops, soil solarization, and low levels of metam sodium were used. However, population densities of these two groups of organisms were significantly lower in plots where methyl bromide was used than in nontreated controls. Population densities were similar for actinomycetes regardless of the treatments.

\section{DISCUSSION}

Soil solarization is known to control soilborne pathogens and pests in subtropical and southern desert regions (21), but there are limited data on its efficacy in the temperate latitudes $(11,24,35)$. Western Oregon, because of its Mediterranean climate (with maximum daily temperatures 25 to $40^{\circ} \mathrm{C}$ and little cloud cover during the summer), should be amenable to solarization. At depths between 5 to $20 \mathrm{~cm}$, the maximum soil temperatures achieved in

Table 4. Disease assessment of maple and cherry trees planted in field plots at Corvallis, OR in May 1997, 8 months after solarization was terminated ${ }^{\mathrm{w}}$

\begin{tabular}{lcc}
\hline Treatment $^{\mathbf{x}}$ & Disease rating $^{\mathbf{y}}$ & ${\text { Trees with galls }(\%)^{\mathbf{z}}}^{\text {Control, noninoculated }}$ \\
Control, solar & $0.7 \mathrm{~b}$ & $3.3 \mathrm{cde}$ \\
Control, nonsolar & $1.5 \mathrm{~cd}$ & $0.7 \mathrm{e}$ \\
Barley, solar & $2.0 \mathrm{de}$ & $9.1 \mathrm{abcd}$ \\
Barley, nonsolar & $1.6 \mathrm{cde}$ & $0.4 \mathrm{e}$ \\
Rape, solar & $1.9 \mathrm{de}$ & $9.5 \mathrm{abc}$ \\
Rape, nonsolar & $1.9 \mathrm{de}$ & $1.3 \mathrm{e}$ \\
Sudan, solar & $2.1 \mathrm{e}$ & $14.2 \mathrm{a}$ \\
Sudan, nonsolar & $1.5 \mathrm{~cd}$ & $2.3 \mathrm{de}$ \\
Metam 230, solar & $2.0 \mathrm{de}$ & $10.6 \mathrm{ab}$ \\
Metam 230, nonsolar & $1.2 \mathrm{bc}$ & $0.0 \mathrm{e}$ \\
Metam 930, nonsolar & $1.9 \mathrm{de}$ & $3.5 \mathrm{bcde}$ \\
Methyl bromide, nonsolar & $1.3 \mathrm{c}$ & $1.4 \mathrm{e}$ \\
& $0.2 \mathrm{a}$ & $4.4 \mathrm{bcde}$ \\
\hline
\end{tabular}

${ }^{w}$ Evaluated in July 1998. Mean values within columns followed by different letters were significantly different $(P<0.01)$ according to the Waller-Duncan procedure.

${ }^{x}$ Solarized plots were covered with a 0.6 -mil clear polyethylene film for 2 months from mid-July to mid-September. Cover crops were planted in May each year and incorporated as green manures in late July. Metam sodium was applied on the soil surface at 230 or 930 liters $\mathrm{ha}^{-1}$ and mechanically incorporated. Methyl bromide was applied at $820 \mathrm{~kg} \mathrm{ha}^{-1}$ under a plastic film.

${ }^{y}$ Verticillium dahliae field maple assay. Rating scale: $1=$ no symptoms, $2=$ few to $9 \%$ of leaves symptomatic, $3=10$ to $49 \%$ of leaves symptomatic, $4=>50 \%$ of leaves symptomatic of Verticillium wilt, and $5=$ dead tree.

${ }^{\mathrm{z}}$ Agrobacterium spp. field cherry assay. Trees were dug and inspected for gall on roots and crown.

this study were within the range of temperatures documented at comparable depths in California (34), Israel (21), and Florida (7). At a 30-cm depth, the maximum temperature recorded was $34^{\circ} \mathrm{C}$ in 1996 , which is 4 to $7^{\circ} \mathrm{C}$ lower than temperatures reported from California (34). At the times of solarization, meteorological conditions were considered normal for western Oregon; therefore, it is anticipated that the reported effects should be repeatable most years.

The efficacy of soil solarization is dependent on the thermal dose (33), a product of the temperature and exposure time, the thermal sensitivity of the organisms, and the chemical, physical, and biological characteristics of the soil, including the moisture content (42). In our study, thermal doses in the upper $10 \mathrm{~cm}$, approximately $150 \mathrm{~h}$ above $40^{\circ} \mathrm{C}$ and $10 \mathrm{~h}$ above $45^{\circ} \mathrm{C}$, were observed each year. These temperatures are in the range of those found to be lethal to many pathogens (2). At 20 and $30 \mathrm{~cm}$, the thermal dose was much lower, but population densities of the pathogens were still reduced, although to a lesser degree. This phenomenon may be due to the cumulative effect of sublethal temperatures on the pathogens $(11,45)$ or to a combination of biological and thermal control, such as increased microbial antagonism or a breakdown in fungistasis (19). There were no significant differences in population densities of the pathogens isolated from soil after 1 or 2 months of solarization; therefore, overall exposure time may be reduced below that tested in this study. However, most nursery crops in the Pacific Northwest are planted in the spring or fall, so there would be no advantage in removing the tarp before the soil is tilled in the fall.

Solarization gave significant reduction in soil population densities of Phy-

Table 5. Greenhouse bioassays of artificially infested soil after two months burial in solarized, fumigated, and cover-cropped field plots at three soil sample depths in Corvallis, OR during $1996^{\mathrm{w}}$

\begin{tabular}{|c|c|c|c|c|c|c|}
\hline \multirow[b]{2}{*}{ Treatment $^{\mathrm{z}}$} & \multicolumn{3}{|c|}{ Mean snapdragon height $(\mathrm{cm})^{\mathrm{x}}$} & \multicolumn{3}{|c|}{ Mean eggplant biomass $(g)^{y}$} \\
\hline & $10 \mathrm{~cm}$ & $20 \mathrm{~cm}$ & $30 \mathrm{~cm}$ & $10 \mathrm{~cm}$ & $20 \mathrm{~cm}$ & $30 \mathrm{~cm}$ \\
\hline Control, sterilized field soil & $19.92 \mathrm{a}$ & $19.92 \mathrm{a}$ & $19.92 \mathrm{a}$ & $6.04 \mathrm{a}$ & $6.04 \mathrm{a}$ & $6.04 \mathrm{a}$ \\
\hline Control, solar & $20.0 \mathrm{a}$ & $18.83 \mathrm{ab}$ & $16.17 \mathrm{ab}$ & $4.19 \mathrm{~d}$ & $3.97 \mathrm{c}$ & $3.31 \mathrm{de}$ \\
\hline Control, nonsolar & $9.67 \mathrm{de}$ & $9.50 \mathrm{~cd}$ & $7.67 \mathrm{de}$ & $3.42 \mathrm{e}$ & $3.17 \mathrm{de}$ & $2.84 \mathrm{def}$ \\
\hline Barley, solar & $17.88 \mathrm{ab}$ & $12.25 \mathrm{c}$ & $11.0 \mathrm{~cd}$ & $4.64 \mathrm{~cd}$ & $3.95 \mathrm{c}$ & $4.25 \mathrm{c}$ \\
\hline Barley, nonsolar & $12.88 \mathrm{~cd}$ & $8.5 \mathrm{~d}$ & $5.88 \mathrm{e}$ & $3.07 \mathrm{ef}$ & $3.09 \mathrm{e}$ & $2.58 \mathrm{ef}$ \\
\hline Rape, solar & $19.38 \mathrm{a}$ & $15.88 \mathrm{~b}$ & $11.25 \mathrm{~cd}$ & $4.5 \mathrm{~cd}$ & 3.38 cde & $3.02 \mathrm{def}$ \\
\hline Rape, nonsolar & $9.50 \mathrm{e}$ & $9.75 \mathrm{~cd}$ & $6.88 \mathrm{de}$ & $2.33 \mathrm{f}$ & $2.33 \mathrm{f}$ & $2.52 \mathrm{f}$ \\
\hline Sudan, solar & $19.88 \mathrm{a}$ & $17.13 \mathrm{ab}$ & $13.88 \mathrm{bc}$ & $5.03 \mathrm{bc}$ & $3.84 \mathrm{~cd}$ & $3.37 \mathrm{~d}$ \\
\hline Sudan, nonsolar & $15.25 \mathrm{bc}$ & $10.75 \mathrm{~cd}$ & 9.88 cde & $2.65 \mathrm{f}$ & $3.21 \mathrm{de}$ & $2.82 \mathrm{def}$ \\
\hline Metam 230, solar & $19.5 \mathrm{a}$ & $17.5 \mathrm{ab}$ & $13.13 \mathrm{bc}$ & $5.04 \mathrm{bc}$ & $4.94 \mathrm{~b}$ & $5.22 \mathrm{~b}$ \\
\hline Metam 930, nonsolar & $20.0 \mathrm{a}$ & $19.63 \mathrm{a}$ & $19.13 \mathrm{a}$ & $5.63 \mathrm{ab}$ & $5.02 \mathrm{~b}$ & $6.44 \mathrm{a}$ \\
\hline
\end{tabular}

${ }^{\mathrm{w}}$ Phytophthora cinnamoni and Verticillium dahliae inoculum was mixed into pasteurized field soil and buried in nylon mess at the start of the solarization period. Mean values within columns followed by different letters were significantly different $(P<0.01)$ according to the Waller-Duncan procedure.

${ }^{x} P$. cinnamomi bioassay: 10 snapdragon plants were planted in plug sheet cells that contained $5 \mathrm{~g}$ of soil from each buried bag mixed in pasteurized field soil. After 7 weeks, plant height was measured.

${ }^{\mathrm{y}} \mathrm{V}$. dahliae bioassay: eggplants were planted in super cells that contained $5 \mathrm{~g}$ of soil from each buried bag mixed in pasteurized field soil. After 7 weeks, plants were harvested, air dried, and weighed.

${ }^{\mathrm{z}}$ Solarized plots were covered with a 0.6-mil clear polyethylene film for 2 months from mid-July to mid-September. Cover crops were planted in May

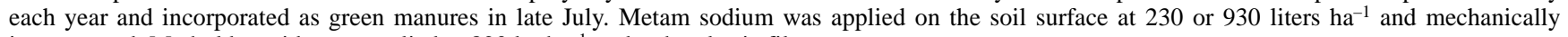
incorporated. Methyl bromide was applied at $820 \mathrm{~kg} \mathrm{ha}^{-1}$ under the plastic film. 
tophthora cinnamomi and $V$. dahliae and subsequent infection by these pathogens of assay plants grown in solarized soil. It has been documented that chlamydospores of $P$. cinnamomi were completely inactivated by exposure to 38 to $41^{\circ} \mathrm{C}$ for $30 \mathrm{~min}$ (3), and that $20 \mathrm{~min}$ at $45^{\circ} \mathrm{C}$ completely killed propagules of $P$. cinnamomi in moist soil and infected walnut twigs (17). In our study, soil temperatures in the top $20 \mathrm{~cm}$ of solarized plots reached above $35^{\circ} \mathrm{C}$ for at least $75 \mathrm{~h}$ in each year. We believe that the thermal dose was sufficient to account for elimination of $P$. cinnamomi in the upper soil profile. At a depth of $30 \mathrm{~cm}$, the lower thermal dose had less effect on the viability of $P$. cinnamomi, as has been previously reported for $P$. cambivora (49). V. dahliae is more tolerant of elevated temperatures, requiring a constant temperature of $45^{\circ} \mathrm{C}$ for 1 to $2 \mathrm{~h}$ to kill $90 \%$ of the microsclerotia under controlled environmental conditions (23). The thermal death curves previously determined $(23,34)$ would predict the high mortality of $V$. dahliae inoculum observed in the upper $10 \mathrm{~cm}$ of the soil profile in our study, but not at lower depths. This prediction was supported by direct assay and bioassay of soils collected from each depth. The initial population densities of $V$. dahliae introduced into the 1996 plots were 50 to 100 times greater than those observed to cause economic loss in susceptible maples varieties in commercial nurseries in Oregon (R. Regan, personal communication). Solarization reduced $V$. dahliae densities to 5 and $25 \%$ of the initial density in 1995 and 1996, respectively. However, the inoculum remaining after solarization resulted in wilt severity that was intermediate to the severity observed in nonsolarized and fumigated plots. Under the lower inoculum densities more typically found in nursery soils, solarization should provide better disease control.

Soil solarization has decreased population densities of both natural and introduced Agrobacterium spp. populations (35). Tests conducted in Italy in 1992 (35) with natural populations showed a decreased population density after soil solarization. Disease incidence was not reduced, however, and, in some cases, there was a slight increase in incidence of crown gall (35). In field experiments in Oregon, where pathogenic strains of Agrobacterium were seeded to soil in 1993 and 1994, Agrobacterium spp. populations were reduced well below those in the control plots, as was the incidence of crown gall on cherry rootstocks subsequently planted to those plots (35). The beneficial effect differed according to soil type. Populations of Agrobacterium spp. in sandy soil were no longer detectable after 6 weeks of solarization. In silty-clay soils, Agrobacterium spp. populations were still detectable after 8 weeks of soil solarization, but the population levels were much lower than those detected when solarization was initiated, indicating that the population was less vulnerable in heavier soils (39). Results from our 1995 and 1996 solarization experiments in silty-clay soil were similar to those reported previously by Raio et al. (35). There was a reduction in population densities of an introduced Agrobacterium strain and a corresponding reduction in the incidence of crown gall in cherry rootstock seedlings. This reduction in the population of Agrobacterium spp. was seen consistently in fallow soil as well as those plots with cover crops. Further studies in solar- ized plots in Italy in 1997 revealed that 12 of 122 rifampicin-resistant isolates from solarized soil were no longer pathogenic and lacked a $\mathrm{Ti}$ plasmid. The 12 strains were identical in biochemical characteristics and total DNA fingerprints to the $A$. rhizogenes strain used to infest soil before solarization. All rifampicin-resistant isolates from nonsolarized soil were pathogenic (36). Therefore, it appears that soil solarization is a beneficial method for reducing the risk of crown gall disease due to lowered populations of agrobacteria and loss of the Ti plasmid.

Cover crops alone or in combination with soil solarization provided no added benefit in terms of reducing populations of Agrobacterium spp. Finally, it is noted that the population density of introduced Agrobacterium spp. pathogens was much higher than those occurring naturally in soil, and solarization, therefore, is likely to be effective in commercial nurseries.

One of the goals of this research was to find substitutes for soil fumigation. Therefore, the relative advantages and disadvantages of various methods must be considered. In our study, fumigation treatments were as effective as the solarization control treatment in reducing Agrobacterium spp. populations in 1996, but metam treatments were less effective than solarization in 1995. This effect also was true relative to the incidence of galled trees in the various plots; that is, all fumigation treatments were not significantly different from the solarized control. Other reports of the effect of soil fumigation on crown gall have been mixed. Deep et al. (12) found that Mazzard cherry seedlings grown in soil fumigated with chloropicrin or a combination of chloropicrin and methyl bro-

Table 6. Recovery of Phytophthora cinnamomi from artificially infested bag samples after 2 months' burial at three depths in solarized, fumigated, and cover-cropped field plots at Corvallis, $\mathrm{OR}^{\mathrm{w}}$

\begin{tabular}{|c|c|c|c|c|c|c|c|}
\hline \multirow[b]{3}{*}{ Treatment $^{\mathrm{y}}$} & \multicolumn{7}{|c|}{ Mean Phytophthora cinnamomi baiting efficacy $(\%)^{x}$} \\
\hline & \multicolumn{3}{|c|}{1995} & \multicolumn{4}{|c|}{1996} \\
\hline & $5 \mathrm{~cm}$ & $10 \mathrm{~cm}$ & $20 \mathrm{~cm}$ & $5 \mathrm{~cm}$ & $10 \mathrm{~cm}$ & $20 \mathrm{~cm}$ & $30 \mathrm{~cm}$ \\
\hline Control, solar & $0 \mathrm{c}$ & $0 \mathrm{c}$ & $16.7 \mathrm{~cd}$ & $0 \mathrm{~d}$ & $0 \mathrm{~d}$ & $11.7 \mathrm{cde}$ & $31.7 \mathrm{c}$ \\
\hline Control, nonsolar & $87.5 \mathrm{a}$ & $93.8 \mathrm{a}$ & $100 \mathrm{a}$ & $88.3 \mathrm{a}$ & $100 \mathrm{a}$ & $100 \mathrm{a}$ & $100 \mathrm{a}$ \\
\hline Barley, solar & $0 \mathrm{c}$ & $0 \mathrm{c}$ & $4.2 \mathrm{~d}$ & $0 \mathrm{~d}$ & $0 \mathrm{~d}$ & $20 \mathrm{~cd}$ & $48.3 \mathrm{bc}$ \\
\hline Barley, nonsolar & $20.8 \mathrm{c}$ & $58.3 \mathrm{~b}$ & $83.3 \mathrm{ab}$ & $30.0 \mathrm{c}$ & $73.3 \mathrm{~b}$ & $83.3 \mathrm{~b}$ & 95 a \\
\hline Rape, solar & $0 \mathrm{c}$ & $0 \mathrm{c}$ & $0 \mathrm{c}$ & $0 \mathrm{~d}$ & $0 \mathrm{~d}$ & 11.7 cde & $36.7 \mathrm{bc}$ \\
\hline Rape, nonsolar & $18.8 \mathrm{c}$ & $58.3 \mathrm{~b}$ & $75.0 \mathrm{~b}$ & $6.7 \mathrm{~d}$ & $43.3 \mathrm{c}$ & $81.7 \mathrm{~b}$ & $96.7 \mathrm{a}$ \\
\hline Sudan, solar & $0 \mathrm{c}$ & $0 \mathrm{c}$ & $0 \mathrm{c}$ & $0 \mathrm{~d}$ & $0 \mathrm{~d}$ & $21.7 \mathrm{c}$ & $53.3 \mathrm{~b}$ \\
\hline Sudan, nonsolar & $58.3 \mathrm{~b}$ & $75 \mathrm{~b}$ & $87.5 \mathrm{ab}$ & $43.3 \mathrm{c}$ & $70 \mathrm{~b}$ & $86.7 \mathrm{ab}$ & $93.3 \mathrm{a}$ \\
\hline Metam 230, solar & $0 \mathrm{c}$ & $0 \mathrm{c}$ & $29.2 \mathrm{c}$ & $0 \mathrm{~d}$ & $0 \mathrm{~d}$ & $0 \mathrm{~d}$ & $3.3 \mathrm{~d}$ \\
\hline Metam 230, nonsolar & $0 \mathrm{c}$ & $0 \mathrm{c}$ & $10.4 \mathrm{~cd}$ & $0 \mathrm{~d}$ & $0 \mathrm{~d}$ & $6.7 \mathrm{de}$ & $11.7 \mathrm{~d}$ \\
\hline Metam 930, nonsolar & $0 \mathrm{c}$ & $0 \mathrm{c}$ & $0 \mathrm{c}$ & $0 \mathrm{~d}$ & $0 \mathrm{~d}$ & $0 \mathrm{~d}$ & $0 \mathrm{~d}$ \\
\hline Methyl bromide, nonsolar & $\mathrm{NT}^{\mathrm{z}}$ & NT & NT & $0 \mathrm{~d}$ & $0 \mathrm{~d}$ & $0 \mathrm{~d}$ & $0 \mathrm{~d}$ \\
\hline
\end{tabular}

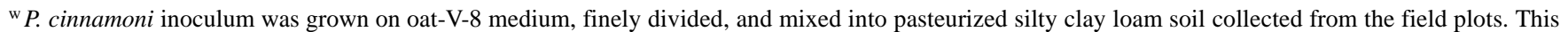
infested soil was placed in nylon mesh bags and buried in plots at the start of the solarization period.

${ }^{\mathrm{x}}$ Eucalyptus leaf disks were floated in a hymexazol solution $\left(25 \mu \mathrm{g} \mathrm{ml}^{-1}\right)$ above assay soil for 3 days at room temperature under fluorescent lighting and then disks were placed into PARP medium amended with $50 \mu \mathrm{g} \mathrm{ml}^{-1}$ hymexazol. After $72 \mathrm{~h}$ of incubation, leaf disk were examined for growth of $P$. cinnamomi and the percent leaf disks colonized was calculated. Mean values within columns followed by different letters were significantly different $(P$ $<0.01$ ) according to the Waller-Duncan procedure.

y Solarized plots were covered with a 0.6-mil clear polyethylene film for 2 months from mid-July to mid-September. Cover crops were planted in May each year and incorporated as green manures in late July. Metam sodium was applied on the soil surface at 230 or 930 liters ha ${ }^{-1}$ and mechanically incorporated. Methyl bromide was applied at $820 \mathrm{~kg} \mathrm{ha}^{-1}$ under the plastic film.

${ }^{\mathrm{z}}$ No treatment was made. 
mide had a higher incidence of crown gall than those grown in nonfumigated soil. Field experiments by $\mathrm{Pu}$ and Goodman (32) resulted in a $84 \%$ reduction in the incidence of crown gall on Chancellor grape in soil previously fumigated with Vorlex (active ingredient: 1-3 dichloropropene and isothiocyanate) at 38 liters $\mathrm{ha}^{-1}$.

Comparisons between the effects of soil solarization and fumigation on beneficial organisms also must be considered. Fumigation by metam sodium showed population decreases ranging from 50 to $90 \%$ of total and culturable bacteria, depending upon the soil type (47). In the current study, population densities of spore-forming Bacillus spp. and fluorescent pseudomonads were reduced by methyl bromide, but were unchanged by solarization.

Our research demonstrated that solarization can reduce, but not eliminate, population densities of Pratylenchus penetrans in the upper $30-\mathrm{cm}$ soil profile. This effect agrees with other reports showing that population densities of Pratylenchus spp. were reduced 50 to $100 \%$ to soil depths of 10 to $15 \mathrm{~cm}$ by solarization, but were not significantly reduced at depths below $15 \mathrm{~cm}(24,31)$. Reinfestation by nematodes migrating from depths below the zone where lethal temperatures were attained (24) may explain why the effects of solarization do not persist throughout the cropping season (7). Given these findings, solarization will not provide adequate control of nematodes in Pacific Northwest nurseries for crops which may have a zero tolerance for nematode infestations in plant materials shipped between states or internationally.

Soil amendments, including crop residues, can reduce the severity of disease caused by plant pathogens (26). Subbarao and Hubbard (44) reported that broccoli residue incorporated in soil reduced the population densities of $V$. dahliae microsclerotia and wilt of cauliflower, and that this effect was greatest at $35^{\circ} \mathrm{C}$. Ramieriz and Munnecke (37) observed that solarization enhanced the activity of amended cruciferous residues in controlling cabbage yellows caused by Fusarium oxysporum f. sp. conglutinans. It was suggested that fungitoxic gases from the decomposing plant residues trapped under the tarp were responsible for disease reduction. In our research, green manure crops alone were effective in reducing populations of $V$. dahliae and Phytophthora cinnamomi, but we did not observe a synergistic interaction between solarization and green manures. Davis et al. (10) reported that 2 to 3 years of cropping with corn or Sudan grass, and subsequent incorporation of the crop residue into the soil, reduced the severity of Verticillium wilt of potato. They hypothesized that root infection by $V$. dahliae was suppressed by nonpathogenic Fusarium spp. which increased in the soil during this period. In our experiments, reduction in population densities of $V$. dahliae occurred both during 8 to 10 weeks of plant growth and after incorporation of residues. Although population densities of $V$. dahliae were reduced following green manure incorporation alone, disease was not decreased in assay plants grown in soil from these treatments.

Soil solarization is well suited for integrated pest management and has been shown to be an economical alternative to fumigation in the subtropics (8). This study demonstrated that conditions in the temperate climate of Oregon were adequate for solarization. Solarization resulted in a significant reduction in population densities of several important pathogens and the diseases which they cause, but in general it was not as effective as fumigation with methyl bromide or high rates of metam sodium for all pathogens at the high population densities used in this study. In temperate regions, solarization in the summer precludes income from the land for one cropping year. Most growers are reluctant to forego the income, at least while fumigants and pesticides are effective and available. However, solarization may be economical in nursery crop production. When plants are dug in the spring, the field can be solarized during the summer, and then replanted in the fall or the following spring. The added benefit of weed control (42) and minimal disturbance to beneficial microorganisms in the soil may make solarization an attractive alternative or supplement to chemical or biological control of pests and pathogens in nursery and other high-value crops.

\section{ACKNOWLEDGMENTS}

We thank T. J. White for technical assistance with aspects of this research.

\section{LITERATURE CITED}

1. Ashworth, L. J., Jr., and Gaona, S. A. 1982. Evaluation of clear polyethylene mulch for controlling Verticillium wilt in established pistachio nut groves. Phytopathology 72:243246.

2. Baker, K. F., and Cook, J. R. 1974. Biological Control of Plant Pathogens. W. H. Freeman and Co., San Francisco.

3. Barbercheck, M. E., and von Broembsen, S. L. 1986. Effects of soil solarization on plant parasitic nematodes and Phytophthora cinnamomi in South Africa. Plant Dis. 70:945-950.

4. Ben-Yephet, Y., Melero-Vera, J. M., and DeVay, J. E. 1988. Interaction of soil solarization and metam-sodium in the destruction of Verticillium dahliae and Fusarium oxysporum f. sp. vasinfectum. Crop Prot. 7:327331.

5. Brisbane, P. G., and Kerr., A. 1983. Selective media for three biovars of Agrobacterium. J. Appl. Bacteriol. 54:425-431.

6. Butterfield, E. J., and DeVay, J. E. 1977. Reassessment of soil assays for Verticillium dahliae. Phytopathology 64:48-51.

7. Chellemi, D. O., Olson, S. M., and Mitchell, D. J. 1994. Effects of soil solarization and fumigation on survival of soilborne pathogens of tomato in northern Florida. Plant Dis. 78:1167-1172.

8. Chellemi, D. O., Olson, S. M., Mitchell, D. J., Secker, I., and McSorley, R. 1997. Adaptation of soil solarization to the integrated management of soilborne pests of tomato under humid conditions. Phytopathology 87:250-258.

9. Clean Air Act. 1990. Title VI. Stratospheric Ozone Protection. Pub L. 101-549, Section 6001. U.S. Congress, Washington, DC.

10. Davis, J. R., Huisman, O. C., Westermann, D. T., Hafez, S. L., Everson, D. O., Sorensen, L. H., and Schneider, A. T. 1996. Effects of green manures on Verticillium wilt of potato. Phytopathology 86:444-453.

11. Davis, J. R., and Sorensen, L. H. 1986. Influence of soil solarization at moderate temperatures on potato genotypes with differing resistance to Verticillium dahliae. Phytopathology 76:1021-1026.

12. Deep, I. W., McNeilan, R. A., and MacSwan, I. C. 1968. Soil fumigants tested for control of crown gall. Plant Dis. Rep. 52:102-105.

13. Freeman, S., and Katan, J. 1988. Weakening effect on propagules of Fusarium by sublethal heating. Phytopathology 78:1656-1661.

14. Greenberger, A., Yogev, A., and Katan, J. 1987. Induced suppressiveness in solarized soils. Phytopathology 77:1663-1667.

15. Halbrent, J. M. 1996. Allelopathy in the management of plant-parasitic nematodes. J. Nematol. 28:8-14.

16. Jeffers, S. N., and Martin. S. B. 1986. Comparison of two media selective for Phy tophthora and Pythium species. Plant Dis. 70:1038-1043.

17. Juarez-Palacios, C., Felix-Gastelum, R Wakeman, R. J., Paplomatas, E. J., and DeVay, J. E. 1991. Thermal sensitivity of three species of Phytophthora and the effect of soil solarization on their survival. Plant Dis. 75:1160-1164.

18. Katan, J. 1980. Solar pasteurization of soils for disease control: Status and prospects. Plant Dis. 64:450-454.

19. Katan, J. 1981. Solar heating (solarization) of the soil for control of soilborne pests. Annu. Rev. Phytopathol. 19:211-236.

20. Katan, J., Fishler, G., and Grinstein, A. 1983 Short- and long-term effects of soil solarization and crop sequence on Fusarium wilt and yield of cotton in Israel. Phytopathology 73:1215-1219.

21. Katan, J., Greenberger, A., Alon, H., and Grinstein, A. 1976. Solar heating by polyethylene mulching for the control of diseases caused by soil-borne pathogens. Phytopathology 66:683-688.

22. Katan, J., Grinstein, A., Greenberger, A., Yarden, O., and DeVay, J. E. 1987. The first decade (1976-1986) of soil solarization (solar heating): A chronological bibliography. Phytoparasitica 15:229-255.

23. Lazarovits, G., Hawke, M. A., Olthof, Th. H A., and Coutu-Sundy, J. 1991. Influence of temperature on survival of Pratylenchus penetrans and on microsclerotia of Verticillium dahliae in soil. Can. J. Plant Pathol. 13:106-111.

24. Lazarovits, G., Hawke, M. A., Tomlin, A. D., Olthof, Th. H. A., and Squire, S. 1991. Soil solarization to control Verticillium dahliae and Pratylenchus penetrans on potatoes in central Ontario. Can. J. Plant Pathol. 13:116123.

25. Linderman, R. G. 1989. Organic amendments and soil-borne diseases. Can. J. Plant Pathol. $11: 180-183$

26. Linderman, R. G., and Zeitoun, F. 1977. Phytophthora cinnamomi causing root rot and wilt of nursery grown native western azalea and salal. Plant Dis. Rep. 61:1687-1690.

27. Mojtahedi, H., Santo, G. S., and Ingham, R E. 1993. Suppression of Meloidogyne chitwoodiI with sudangrass cultivars as green manures. J. Nematol. 25:303-311.

28. Moore, L. W., Kado, C. I., and Bouzar, H 
1988. II. Gram-Negative Bacteria: Agrobacterium. Pages 16-36 in: Laboratory Guide for Identification of Plant Pathogenic Bacteria. 2nd ed. N. W. Schaad, ed. APS Press, St. Paul, MN.

29. Muehlchen, A. M., Rand, R. E., and Parke, J. L. 1990. Evaluation of crucifer green manure for controlling Aphanomycetes root rot of peas. Plant Dis. 74:651-654.

30. Pinkas, Y., Kariv, A., and Katan, J. 1984. Soil solarization for the control of Phytophthora cinnamomi: Thermal and biological effects. (Abstr.) Phytopathology 74:796.

31. Porter, I. J., and Merriman, L. R. 1983. Effects of solarization of soil on nematode and fungal pathogens at two sites in Victoria. Soil Biol. Biochem. 15:39-44.

32. Pu, X. A., and Goodman, R. N. 1993. Effects of fumigation and biological control on infection of indexed crown gall free grape plants. Am. J. Enol. Vitic. 44:241-249.

33. Pullman, G. S., DeVay, J. E., and Garber, R. H. 1981. Soil solarization and thermal death: A logarithmic relationship between time and temperature for four soilborne plant pathogens. Phytopathology 71:959-964.

34. Pullman, G. S., DeVay, J. E., Garber, R. H., and Weinhold, A. R. 1981. Soil solarization: Effects of Verticillium wilt of cotton and soilborne populations of Verticillium dahliae, Pythium spp., Rhizoctonia solani, and Thielaviopsis basicola. Phytopathology 71:954-959.

35. Raio, A., Zoina, A., and Moore, L. W. 1997. The effect of solar heating of soil on natural and inoculated agrobacteria. Plant Pathol.
46:320-328.

36. Raio, A., Zoina, A., and Moore, L. W. 1998. Loss of Agrobacterium tumefaciens tumor inducing plasmid in solarized soil. Works. Proc. Mol. Approaches Biol. Control, Delemont, Switzerland. B. Duffy, U. Rosenberger, and G. Defago, eds. Int. Organ. Biol. Integrated Control Noxious Animals Plants, WPRS Bull. 21(9):301-304.

37. Ramirez-Villapudua, R. J., and Munnecke, D. E. 1988. Effect of solar heating and soil amendments of cruciferous residues on Fusarium oxysporum f. sp. conglutinans and other organisms. Phytopathology 78:289-295.

38. Sorensen, L. H., Schneider, A. T., and Davis, J. R. 1991. Influence of sodium polygalacturonate sources and improved recovery of Verticillium spp. from soil. (Abstr.) Phytopathology 81:1347.

39. Stapleton, J. J., and DeVay, J. E. 1982. Effect of soil solarization on populations of selected soilborne microorganisms and growth of deciduous fruit tree seedlings. Phytopathology 72:323-326.

40. Stapleton, J. J., and DeVay, J. E. 1983. Response of phytoparasitic and free-living nematodes to soil solarization and 1,3-dichloropropene in California. Phytopathology 73:1429-1436

41. Stapleton, J. J., and DeVay, J. E. 1984. Thermal components of soil solarization as related to changes in soil and root microflora and increased growth response. Phytopathology 74:255-259.

42. Stapleton, J. J., and DeVay, J. E. 1986. Soil solarization: A non-chemical approach for management of plant pathogens and pests. Crop Prot. 5:190-198.

43. Stapleton, J. J., and Heald, C. M. 1991. Management of phytoparasitic nematodes by soi solarization. Pages 51-59 in: Soil Solarization. J. Katan, and J. E. DeVay, eds. CRC Press, Inc., Boca Raton, FL.

44. Subbarao, K. V., and Hubbard, J. C. 1996. Interactive effects of broccoli residues and temperature on Verticillium dahliae microsclerotia in soil and on wilt of cauliflower Phytopathology 86:1303-1310.

45. Tjamos, E. C., and Paplomatas, E. J. 1988 Long-term effect of soil solarization in controlling Verticillium wilt of globe artichokes in Greece. Plant Pathol. 37:507-515.

46. Townshend, J. L. 1963. A modification and evaluation of the apparatus for the Oostenbrink direct cottonwool filter extraction method. Nematologica 9:106-110.

47. Toyota, K., Ritz, K., Kuninaga, S., and Kimura, M. 1999. Impact of fumigation with metam sodium upon soil microbial community structure in two Japanese soils. Soil Sci. Plant Nutr. 45:207-223.

48. VanEatten, C. H., and Tookey, H. L. 1979 Chemistry and biological effects of glycosinolates. Pages 471-500 in: Herbivores: Their Interaction with Secondary Plant Metabolites. C. A. Rosenthal and D. H. Janzen, eds. Academic Press, New York.

49. Wicks, T. J. 1988. Effect of solarisation on the control of Phytophthora cambivora in almond and cherry. Aust. J. Exp. Agric. 28:539-545. 